\section{Lax standards confirmed}

\section{London}

VIKTOR Bryukhanov, director of the Chernobyl nuclear power station at the time of the 1986 disaster, has at last broken his silence and given an interview to the newspaper Sotsialisticheskaya Industriya. Bryukhanov, who is serving a 10 -year sentence in a labour colony, had been afraid that any statement he might make would be interpreted as self-justification. "And I was guilty", he admits, "only not as guilty as the court decided." On the night of the ill-conceived experiment that ended in explosion, Bryukhanov was at home in the nearby town of Prypyat.

He was awoken, he says, by a telephone call from the head of the chemical unit who told him only that "something awful has happened - some sort of explosion". Imagining something like a ruptured steam-line, he hurried to the station, but when he saw that the top of number four block was completely missing, "my heart stood still", he says. $\mathrm{He}$ telephoned Moscow and tried to order an immediate evacuation, but no one would support him because it was "so firmly fixed in their minds that nothing could happen to the reactor".

Bryukhanov's account confirms the picture which emerged at the post-accident review conference held by the International Atomic Energy Agency of a naive faith in the safety of nuclear power coupled with a neglect of the very rules and procedures on which safety depended. But as director of the Chernobyl power plant from its inception, he is able to reveal the background to this atmosphere of rule-breaking. Starting with a green-field site, he had to oversee the construction not only of the power station itself but also temporary accommodation and later a town for the site-workers. He found himself coping with broken heating systems and failing supplies of fresh vegetables and, unlike the directors of manufacturing plants, he had nothing he could barter to get consumer goods for his workers.

Bryukhanov maintains that without rule-breaking, the Chernobyl station would never have been completed. Electric cables, for example, should have had fire-resistant claddings, but none was available and ordinary cables were used instead. He says he was worried about the situation, but knew that if he made a fuss he would simply be replaced by a new and more amenable director. "It is not within the power of one man to overthrow a system of economic-management relationships which has built up over decades. And he should not be held guilty if in the end he becomes the slave of that system."

But Bryukhanov was found guilty while

\section{CLINICAL RESEARCH}

others in higher places escaped to honourable retirements. Long before the Chernobyl accident, he says, scientists from the Kurchatov Nuclear Energy Institute warned Academician Anatolii Aleksandrov (president of the Academy of Sciences and a leading supporter of nuclear power) of design faults in the RBMK reactor, but nothing was done.

After the accident, the safety systems were tightened up, making it impossible to withdraw many control rods (as was done at Chernobyl) and considerably reducing the automatic shut-down time. Yet Bryukhanov says he is not certain that events similar to those of Chernobyl will not be repeated elsewhere.
Bryukhanov has been heavily criticized since the accident, and the attacks continue. Only last summer, the weekly Argumenty $i$ Fakty said that the three operators who carried out the ill-fated experiment on the reactor did not know that pulling out too many rods could cause an explosion. Their superiors did know, the paper said, but they were safely asleep at home.

Whether Bryukhanov did know the full danger and could have stopped the experiment is unclear. He portrays himself as a man in an impossible job, who was made the scapegoat when disaster struck. In the words of Georgii Kopchinskii, head of the Department of Atomic Energy of the Bureau of the Council of Ministers of the USSR, the court "did not judge the man, but the job".

Vera Rich

\title{
Network of centres better than just one
}

\section{London}

PLANS by the UK Medical Research Council (MRC) to establish a national clinical research centre have been rejected by the Advisory Board for the Research Councils (ABRC), which favours instead a network of provincial research centres. These, says the ABRC, will meet the desired aims of improving the quality of science and the standards of medical training and hospital practice, but will be more cost-effective than the MRC's strategy.

Although Dr David Rees, MRC secretary, welcomed the ABRC's support for the clinical research initiative, he was disappointed that it had not approved the idea of a single centre of excellence. The proposed centre would have been located at Hammersmith Hospital, in association with the Royal Postgraduate Medical School, at an initial estimated cost of $£ 100$ million. That figure was later scaled down to $£ 50$ million after the $\mathrm{ABRC}$ requested that funds be released for other leading clinical research centres in the United Kingdom.

The ABRC recommends that the Hammersmith centre should be fostered, and that the Clinical Research Centre (CRC) at Northwick Park should be closed so that resources can be redirected to the provincial centres. Sir David Phillips, ABRC chairman, in a letter to John MacGregor, Secretary of State for Education and Sciences, says there is a strong case for "enhancing and sustaining" clinical research at the RPMS through an infusion of basic biomedical research, but adds that the ABRC does not favour a single national centre, preferring a "distributed approach" with "phased devel opments" at a number of provincial centres. Phillips concludes that this programme would cost "significantly less" than the single-centre option.
MacGregor said he was "naturally pleased" that the ABRC's preference on merit was for the cheaper approach. Dr James Scott, of the CRC, said the MRC had "gone for the stars" in asking for backing in the national research centre initiative and that it should not be too disappointed that it had not got complete support. He said the CRC had not been the success it should have been and that clinical research needed to "pull its socks up". BenWebb

\section{AIDS \\ AZT for children in extended US trial}

\section{Washington}

ThE US Food and Drug Administration (FDA) last week approved the use of the anti-AIDS drug AZT (zidovudine) to treat children.

Under the terms of a treatment IND (investigational new drug) programme, AZT will be provided free of charge by its manufacturer, Burroughs Wellcome, not only for children showing symptoms of AIDS but also for those lacking symptoms but in the advanced stages of infection with HIV (human immunodeficiency virus).

Two months ago, on the basis of trial results demonstrating that AZT slowed the progress of HIV infection, the drug was made available to asymptomatic but infected adults as well as those with overt AIDS. The new extension is also based on trial results: a study of more than 200 children has shown that AZT can both relieve symptoms and prolong survival. What had held back use of the drug for children was the fear that side-effects could be more severe in children than in adults, but the study results so far indicate that side-effects are not qualitatively different in children.

David Lindley 